Linguista: Jurnal IImiah Bahasa, Sastra, dan Pembelajarannya

Vol.3, No.2, Desember 2019, hal 105-119

ISSN (print): 2579-8944; ISSN (online): 2579-9037

Avaliable online at: http:/le-journal.unipma.ac.id/index.php/linguista

\title{
Pengaruh Kualitas Pelaksanaan Gerakan Literasi dan Minat Baca Terhadap Hasil Belajar Berbicara Siswa SD Negeri Segugus Taman, Kota Madiun
}

\author{
Ririn Nuryanti \\ SDN 02 Taman, Jl. Pesanggrahan VII No.4,, Madiun, Indonesia \\ e-mail: ririn_nuryanti@gmail.com
}

\begin{abstract}
Abstrak
Penelitian ini bertujuan untuk (1) menemukan pengaruh kualitas pelaksanaan Literasi

Sekolah terhadap hasil belajar berbicara siswa SD Negeri segugus Taman kota Madiun; (2) menemukan pengaruh minat membaca terhadap hasil belajar berbicara siswa SD Negeri segugus Taman kota Madiun. (3) menemukan interaksi antara kualitas pelaksanaan literasi dan minat membaca terhadap hasil belajar berbicara siswa SD Negeri segugus Taman kota Madiun.Metode Penelitian yang digunakan adalah metode quasi eksperiment dengan desain penelitian factorial $2 \times 2$. Teknik pengumpulan data menggunakan angket untuk gerakan literasi sekolah dan minat baca, serta hasil belajar berbicara .Informan dalam penelitian ini adalah siswa kelas V.Teknik analisis data menggunakan Anava dua jalan dengan program SPSS versi 13. Dari analisis Inferensial diperoleh simpulan: (1) Ada pengaruh kualitas pelaksanaan gerakan literasi sekolah terhadap hasil belajar berbicara siswa SD secara signifikan antara kelompok kualitas pelaksanaan gerakan literasi tinggi dengan kualitas pelaksanaan gerakan literasi rendah. (2) Ada pengaruh minat baca terhadap prestasi berbicara siswa SD secara signifikan antara kelompok minat baca tinggi dengan minat baca rendah. (3) Ada interaksi antara kualitas pelaksanaan literasi dan minat baca terhadap prestasi belajar berbicara siswa SD secara signifikan ditinjau dari antara pelaksanaan gerakan literasi dengan minat baca.
\end{abstract}

Kata kunci: Gerakan Literasi Sekolah; Minar Baca; Hasil Belajar Siswa.

\section{The Influence of the Quality of Literacy Movement Implementation and Students' Interests of Reading on Students' Learning Outcomes in Elementary School of Taman Cluster, Madiun City}

\begin{abstract}
This study aims to (1) find the effect of the quality of the implementation of School Literacy on the learning outcomes of students speaking at elementary school students in Taman Cluster, Madiun city; (2) find the influence of interest in reading on the results of learning to speak elementary school students in Taman Cluster, Madiun city; (3) find an interaction between the quality of literacy implementation and reading interest in the learning outcomes of students speaking at elementary school students in Taman Cluster, Madiun city. The research method used was a quasi experimental method with $2 \times 2$ factorial research designs. Data collection techniques were using a questionnaire for school literacy movements and interest in reading, as well as learning outcomes of learning. The participants in this study were the fifth grade students. The data analysis technique used was Anava two ways with SPSS version 13. From the Inferential analysis, it can be concluded that: (1) There is a significant influence of the quality of the implementation of the school literacy movement towards the learning outcomes of elementary school students between the groups of the quality of the implementation of
\end{abstract}


the high literacy movement and the quality of the implementation of the low literacy movement. (2) There is a significant influence of reading interest on elementary students' speaking achievement between high reading interest groups and low reading interest groups. (3) There is an interaction between the quality of literacy implementation and reading interest on the learning achievement of elementary school students significantly in terms of between the literacy movement implementation and reading interest.

Keywords: Schol Literacy Movemenet; Reading Interest; Student's Learning Outcome.

\section{Pendahuluan}

Sesuai amanat undang undang, Literasi memegang peran penting dalam pembelajaran di SD. Kemampuan literat yang baik pada siswa, mendorong pengembangan kemampuan lain, sebab literat merupakan kemampuan dasar untuk memperoleh kemampuan pada bidang yang lain. Menurut penelitian dalam PISA (Programme for International Students Assesment) tahun 2012 pada 65 negara di seluruh dunia menunjukkan kemampuan literasi peserta didik dengan usia 15 tahun. Indonesia menempati peringkat 64 dari 65 negara dengan capaian skor sebesar 375 hanya unggul atas Peru dibawahnya.Dengan hasil ini menunjukkan bahwa sistem pendidikan di Indonesia saat ini masih belum bisa menghasilkan kemampuan literasi yang bersaing dengan negara lain (OECD, 2014:5). Untuk itu sekolah sebagai organisasi pembelajaran, melalui GLS, sekolah berupaya untuk menumbuhkan minat membaca siswa. Konsep literasi sebagai memahami dan melahirkan istilah literasi produktif dan literasi reseptif. Konsep ini merujuk pada upaya memahami melalui aktifitas berbahasa pasif (membaca, menyimak), dan upaya memahami melalui aktifitas berbahasa aktif (menulis dan berbicara).

Gerakan literasi sekolah diharapkan mampu mendorong siswa untuk memiliki kebiasaan membaca.Jika pembiasaan membaca ini sudah terbentuk maka membaca tidak lagi menjadi paksaan melainkan menjadi suatu kebutuhan.Menurut Tarigan (2008:7) membaca adalah suatu proses yang dilakukan serta dipergunakan oleh pembaca untuk memperoleh pesan yang hendak disampaikan oleh penulis melalui media kata-kata/bahasa tulis. Dalam membaca, seseorang akan berusaha untuk memahami isi dan informasi yang hendak disampaikan oleh penulis. Untuk itu membaca memiliki manfaat untuk menambah wawasan dan pengetahuan.Dalam dunia pendidikan, membaca menjadi prioritas yang penting bagi siswa. Siswa akan memperoleh informasi yang dibutuhkan untuk meningkatkan diri lebihmaju.

Kegiatan yang dilakukan dalam gerakan literasi sekolah adalah membiasakan siswa membaca buku selama 15 menit sebelum kegiatan belajar mengajar dimulai.Buku yang dibaca adalah buku non pelajaran yang disukai oleh siswa. Ketika pembiasaan sudah terbentuk selanjutnya siswa akan dibimbing untuk mencapai tahap selanjutnya yaitu pengembangan dan pembelajaran. Dalam tahap ini siswa tidak hanya diminta untuk membaca saja namun juga memahami isi bacaan yang dibaca.Dengan demikian membiasakan siswa untuk dapat memgembangkan kemampuannya dalam memahami bacaan sehingga pengetahuan yang diperoleh dari membaca dapat dikuasai denganbaik.

Berbicara menurut greene dan Petty (Tarigan, 2008:3-4) bahwa berbicara adalah suatu keterampilan berbahasa yang berkembang pada kehidupan anak anak, yang hanya didahului oleh keterampilan menyimak, dan pada masa tersebutlah kemampuan 
berbicara atau berujar dipelajari. Berbicara sudah barang tentu berhubungan erat dengan perkembangan kosa kata yang diperoleh oleh sang anak; melalui kegiatan menyimak dan membaca. Kebelum matangan dalam perkembangan bahasa juga merupakan suatu keterlambatan dalam kegiatan kegiatan berbahasa. Kemampuan mengucapkan bunyi-bunyi artikulasi atau kata-kata untuk mengekpresikan, menyatakan atau menyampaikan pikiran, gagasan, dan perasaan. Sebagai perluasan ini berbicara merupakan suatu sistem tanda-tanda yang dapat didengar (audible) dan yang kelihatan (visible) yang memanfaatkan otot dan jaringan otot tubuh manusia demi maksud dan tujuan gagasan-gagasan atau ide-ide yang dikombinasikan. Berbicara juga merupakan suatu bentuk prilaku manusia yang memanfaatkan faktor faktor fisik, psikologis, neurologis, semantik, dan linguistik sedemikian ekstensif, secara luas sehingga dapat dianggap sebagai alat manusia yang paling penting bagi kontrol manusia. (Tarigan, 2008:16)

Keterampilan berbicara diartikan pada hakikatnya merupakan keterampilan memproduksi arus sistem bunyi artikulasi untuk menyampaikan kehendak, kebutuhan perasaan, dan keinginan kepada orang lain. Dalam hal ini, kelengkapan alat ucap seseorang merupakan persyaratan alamiah yang memungkinkan untuk memproduksi suatu ragam yang luas bunyi artikulasi, tekanan, nada, kesenyapan, dan lagu bicara.Keterampilan ini juga didasari oleh kepercayaan diri untuk berbicara secara wajar, jujur, benar, dan bertanggung jawab dengan menghilangkan masalah psikologis seperti rasa malu, rendah diri, ketegangan, berat lidah, dan lain-lain (Iskandarwassid dan Suhendar, 2015: 241). Semakin sering berlatih atau belajar orang akan semakin terampil. Analogi tersebut tampaknya tepat bila dihubungkan dengan keterampilan berbahasa yang diterapkan kepada siswa. Semakin siswa diberikan kesempatan belajar dan berlatih akan semakin berkembang dan terampil kemampuan berbahasanya. Dengan demikian peran guru dalam melakukan proses pembelajaran dengan memilih pendekatan, metode, dan teknik yang tepat dalam pembelajaran sangat menentukan keberhasilan keterampilan berbahasa siswa khususnya yang peneliti lakukan dengan mengaktifkan keterlibatan siswa dalam berkomunikasi.

Tujuan utama berbicara adalah untuk berkomunikasi.Agar dapat menyampaikan pikiran secara efektif, pembicara harus memahami makna segala sesuatu yang ingin dikomunikasikan.Pada dasarnya berbicara mempunyai tiga tujuan umum, yaitu memberitahukan dan melaporkan (to inform), menjamu dan menghibur (to entertain), membujuk, mengajak, mendesak, dan meyakinkan (to persuade) (Tarigan, 2008: 16). Tujuan pembelajaran berbicara pada siswa SD dalam (BSNP 2006) dinyatakan bahwa lulusan SD diharapkan dapat menggunakan bahasa sesuai dengan situasi dan tujuan berbahasa.Tujuan Pembelajaran Berbicara pada siswa SD adalah siswa diharapkan mampu berbicara secara efektif untuk mengungkapkan gagasan, pendapat dan perasaaan dalam berbagai bentuk dan cara kepada berbagai bentuk dan cara kepada berbagai sasaran sesuai dengan tujuan dan kontek pembicaraan.

Kegiatan berbicara dapat berlangsung jika setidak tidaknya ada dua orang yang berinteraksi, atau sesorang pembicara menghadapi seorang lawan bicara. Kegiatan berbicara bermakna juga dapat terjadi jika salah satu pembicara memerlukan informasi baru atau ingin menyampaikan informasi penting pada orang lain. Karakteristik yang harus ada dalam pembelajaran berbicara di sekolah dasar yaitu ; (a) harus ada lawan bicara, (b) pengusaan lafal, struktur dan kosa kata, (c) ada tema atau topik yang 
dibicarakan, (d) ada informasi yang ingin disampaikan atau sebaliknya ditanyakan, (e) memperhatikan situasi dan konteks

Metode pengajaran berbicara yang baik harus memenuhi beberapa kriteria yang berkaitan dengan ketiga hal itu. Beberapa kriteria yang harus dipenuhi oleh metode pengajaran, yaitu (1) relevan dengan tujuan, (2) cocok dengan pelajaran, (3) memudahkan siswa memahami materi pengajaran, (4) mengembangkan butir-butir keterampilan proses, (5) dapat mewujudkan pengalaman belajar yang telah dirancang, (6) tidak menuntut peralatan yang rumit, (7) mudah dilaksanakan, ( 8 ) menciptakan suasana belajar yang menyenangkan (T.W.Solchan,2013: 11.33). Menurut Sumiati, dkk, dalam Metode pembelajaran $(2008,96)$, metode Pembelajaran sangat beragam dalam pengajaran bahasa Indonesia terdapat bermacam macam metode yang dapat diterapkan.Berikut merupakan metode dalam pengajaran bahasa Indonesia.1) Metode Langsung, 2). Metode Alamiah, 3). Metode Tatabahasa,4). Metode Terjemahan, 5). Metode Pembatasan Bahasa, 6). Metode Linguistik, 7). Metode SAS, 8).Metode Bibahasa, 9) Metode Unit.

Penilaian pada hakikatnya merupakan suatu proses, yang menurut cronbach ( 1963, lewat Burhan Nurgiyantoro, 1988: 188) adalah proses pengumpulan dan penggunaan informasi yang dipergunakan sebagai dasar pembuatan keputusan tentang program pendidikan. Penilaian berbicara adalah suatu proses pengumpulan dan penggunaan informasi yang dipergunakan sebagai dasar pembuatan keputusan mengukur kemampuan siswa dalam penguasaan masalah dan atau gagasan yang disampaikan, serta kemampuan memahami bahasa lawan bicara. Suatu penilaian perlu mengikuti langkah langkah sebagai berikut. Langkah pertama adalah perencanaan yang berisi kegiatan-kegiatan perumusan tujuan penilaian, menetapkan aspek-aspek yang akan dinilai, menentukan metode penilaian yang dipergunakan, penyusunan alat penilaian, penentuan kriteria yang dipergunakan, dan menentukan frekuensi pelaksanaan penilaian. Langkah kedua adalah pengumpulan data yang merupakan kegiatan-kegiatan pelaksanaan penilaian, memeriksa hasil penilaian atau lembar tugas, dan pemberian skor. Langkah ketiga adalah pengelolaan data hasil penilaian yang mungkin dilakukan dengan teknik statistik atau nonstatistik, tergantung jenis data yang diperoleh yang kuantitatif atau kualitatif. Langkah keempat adalah penafsiran terhadap hasil kegiatan pengolahan data dengan didasarkan diri pada norma tertentu. Langkah terakhir adalah penggunaan hasil penilaian yang telah selesai diolah dan ditafsirkan sesuai dengan tujuan dilakukannya penilaian. (Nurgiyantoro, 2009 : 9-10)

Bentuk kemampuan berbicara yang dipilih memungkinkan siswa untuk tidak saja mengungkapkan kemampuan berbahasanya, melainkan juga mengungkapkan gagasan, pikiran, atau perasaannya. Dengan demikian tes tersebut bersifat fungsional, disamping dapat mengungkapkan kemampuan siswa berbicara dalam bahasa yang bersangkutan mendekati pemakaiannya secara normal. Adapun bentuk-bentuk tugas atau tes berbicara sebagai berikut.1) Pembicaraan berdasarkan gambar, 2) Wawancara, (3) Bercerita, 4) Pidato, 5) Diskusi. Penilaian kemampuan berbicara hendaknya mencakup dua aspek yaitu keterampilan dan kemampuan kognitif. Aspek keterampilan terutama dari segi kelaancaran dan kewajaran gerakan, sedangkan kemampuan kognitif mencakup ranah tingkat ingatan (C1) sampai dengan tingkat penillaian (C6). Adapun tingkat kemampuan berbicara adalah (1) Tes kemampuan berbicara tingkat ingatan, (2)

Linguista Vol. 3, No. 2, Desember 2019: 105-119 
Tes kemampuan berbicara tingkat pemahaman, (3) Tes Kemampuan berbicara tingkat penerapan. Nurgiantoro (2009: 291-294)

Belajar merupakan proses perubahan perilaku yang merupakan hasil pengalaman, dan hal itu tidak dikaitkan dengan keadaan sementara ( Hemati \& Moradi, 2013). Belajar adalah serangkaian kegiatan jiwa raga untuk memperoleh suatu perubahan tingkah laku sebagai hasil dari pengalaman individu dalam interaksi dengan lingkungannya yang menyangkut kognitif, afektif, dan psikomotor (Syaiful Bahri Djamarah, 2011: 13). Belajar diartikan sebagai proses perubahan tingkah laku padadiri individu berkat adanya interaksi antara individu dan individu dengan lingkungannya (Uzer Usman, 2006:5). Dan menurut Sudijono (2012, 32) hasil belajar merupakan sebuah tindakan evaluasi yang dapat mengungkap aspek proses berpikir (cognitive domain) juga dapat mengungkap aspek kejiwaan lainnya, yaitu aspek nilai atau sikap ( affective domain) dan aspek keterampilan (psychomotor domain) yang melekat pada diri setiap individu perserta didik. Hasil belajar berbicara adalah merupakan hasil penilaian yang diperoleh dari proses tindakan evaluasi yangberupa kemampuan intektual, strategi kognitif, informasi verbal, sikap, dan keterampilan menyampaikan pesan atau gagasan secara lisan.

Pengukuran hasil belajar merupakan bagian penting dalam proses belajar mengajar, karena dengan pengukuran tersebut dapat ditentukan tingkat keberhasilan suatu program sekaligus juga dapat dinilai baik atau buruknya suatu program pembelajaran. Untuk mengukur hasil belajar siswa yaitu dengan menggunakan alat ukur (test) sebagaimana yang dijelaskan (Purwanto,1994; 3). Adapun tes untuk mengukur hasil belajar berbicara dapat berupa tes berbicara berdasar gambar, tes wawancara, tes bercerita, tes berpidato, dan tes berdiskusi (Nurgiantoro, 2009: 278)

Secara etimologis literasi berasal dari bahasa latin littera yang memiliki pengertian sistem tulisan yang menyertainya. Liteasi adalah hak asasi manusia yang fundamental dan pondasi untuk belajar sepanjang hayat (Malawi dkk, 2017: 6). Sebagaimana pendapat Goody ( 1999), Pengertian literasi dalam arti sempit adalah kemampuan untuk membaca dan menulis. Pendapat lain tentang pengertian literasi disampaikan oleh Cordon ( 2003) yang menyatakan bahwa literasi adalah ilmu yang menyenangkan, yang mampu membangun imajinasi para siswa untuk menjelajah dunia dan ilmu pengetahuan. Shihab $(1996 ; 5)$ dalam bukunya yang berjudul Wawasan AlQuran menegaskan bahwa perintah membaca adalah sesuatu yang paling berharga yang pernah dan bisa diberikan untuk umat manusia."Membaca" dalam berbagai makna yang terkandung di dalamnya merupakan syarat pertama dan utama bagi perkembangan ilmu pengetahuan dan teknologi sekaligus membangun peradaban. Sejarah membuktikan bahwa peradaban-peradaban yang berhasil eksis dan tahan lama, justru diawali dari sebuah kitab (bacaan). Deklarasi Praha pada tahun 2003 menyebutkan bahwa literasi juga mencakup bagaimana seseorang berkomunikasi dalam masyarakat. Literasi juga bermakna praktik dan hubungan sosial yang terkait dengan pengetahuan, bahasa, dan budaya (UNESCO, 2003). Deklarasi UNESCO itu juga menyebutkan bahwa literasi informasi terkait pula dengan kemampuan untuk mengidentifikasi, menentukan, menemukan, mengevaluasi, menciptakan secara efektif dan terorganisasi, menggunakan dan mengomunikasikan informasi untuk mengatasi berbagai persoalan. Kemampuan itu perlu dimiliki tiap individu sebagai syarat untuk berpartisipasi dalam masyarakat informasi, dan itu bagian dari hak dasar manusia 
menyangkut pembelajaran sepanjang hayat. Literasi sebagai kemampuan seseorang dalam mengolah dan memahami informasi saat melakukan proses membaca dan menulis. Literasi juga bermakna praktik dalam hubungan sosial yang terkait dengan pengetahuan, bahasa, dan budaya. Literasi mencakup bagaimana seseorang berkomunikasi dalam masyarakat. Kualitas Pelaksanaan Literasi sekolah dinyatakan tinggi apabila sudah sesuai dengan tahapan yang telah ditetapkan oleh buku panduan pelaksanaan literasi sekolah, namun apabila pelaksanaan literasi sekolah ada sebagaian yang belum sesuai dengan tahapan yang telah ditetapkan dalam buku panduan pelaksanaan litersi sekolah maka kualitas pelaksanaan literasi sekolah dinyatakan rendah.

Menurut Noeng Muhajir (Dwi Sunar Prasetyono, 2008: 54), minat adalah kecenderungan afektif (perasaan, emosi) seseorang untuk membentuk aktifitas. Dari sini dapat dilihat bahwa minat itu melibatkan kondisi psikis (kejiwaan) seseorang. Senada dengan hal ini. Minat merupakan rasa lebih suka dan rasa ketertarikan pada suatu hal atau aktifitas, tanpa ada yang menyuruh (Slameto, 2010: 180). Menurut Hurlock (Hermanto, 2011), mengartikan minat sebagai sumber motivasi yang akan mengarahkan seseorang pada apa yang akan mereka lakukan bila diberi kebebasan untuk memilihnya. Bila mereka melihat sesuatu itu mempunyai arti bagi dirinya, maka mereka akan tertarik terhadap sesuatu itu yang pada akhirnya nanti akan menimbulkan kepuasan bagi dirinya. Minat dapat diartikan sebagai suatu kecenderungan perasaan manusia untuk memberikan perhatian dan menikmati beberapa aktivitas dan merasakan kepuasan setelah melaksanakan hal yang diminati.

Pintrich dan Schunk (1996) menyebutkan aspek - aspek minat adalah sebagai berikut:a). Sikap umum terhadap aktivitas (general attitude toward the activity) sikap umum disini maksudnya adalah sikap yang dimiliki oleh individu, yaitu perasaan suka atau tidak suka terhadap aktivitas.b). Pilihan spesifik untuk menyukai aktivitas (spesific preference for or liking the activity). Individu akan memutuskan pilihannya untuk menyukai aktivitas tersebut. c). Merasa senang dengan aktivitas (enjoyment of the activity), yaitu perasaan senang individu terhadap segala sesuatu yang berhubungan dengan aktivitasnya. d). Aktivitas tersebut mempunyai arti atau penting bagi individu (personel importance or significance of the activity to the individual) individu merasa bahwa aktivitas yang dilakukannya sangat berarti. e). Adanya minat intrisik dalam isi aktivitas (instrinsic interest in the contentof activity). Dalam aktivitas tersebut terdapat perasaan yang menyenangkan. f). Berpartisipasi dalam aktivitas (reported choise of or participation in theactivity). Individu akan berpartisipasi dalam aktivitas itu karena menyukainya.

Menurut Rahim (2008:28), minat baca adalah keinginan yang kuat disertai usaha-usaha seseorang untuk membaca. Seseorang yang mempunyai minat membaca yang kuat akan diwujudkan dalam kesediaannya untuk mendapat bahan bacaan dan kemudian membacanya atas kesadarannya sendiri. Minatbaca

merupakan kecenderungan jiwa yang mendorong seseorang berbuat sesuatu terhadap membaca (Darmono, 2001: 182). Definisi tersebut senada dengan pendapat Sandjaya yang menyatakan bahwa minat baca adalah suatu perhatian yang kuat dan mendalam disertai dengan perasaan senang terhadap kegiatan membaca sehingga dapat mengarahkan seseorang untuk membaca dengan kemauan sendiri (Sandjaja, 2005). Minat baca merupakan suatu rasa lebih suka dan rasa lebih ketertarikan pada 
kegiatan penafsiran yang bermakna terhadap bahasa tulis (membaca) yang ditunjukkan dengan keinginan, kecenderungan untuk memperhatikan aktivitas tersebut tanpa ada yang menyuruh atau dilakukan dengan kesadarannya, diikuti dengan rasa senang serta adanya usaha-usaha seseorang untuk membaca tersebut dilakukan karena adanya motivasi dari dalam diri dalam proses pembelajar sepanjang hayat.

\section{Metode Penelitian}

Metode yang digunakan dalam penelitian ini adalah metode eksperimen dengan rancangan penelitian eksperimen semu (quasi-experimental research). Quasi experiment is used when random assignment of subjects to experimental and control groups is not possible and has not been done (Borg \& Gall, 1979: 556-557). Penelitian eksperimen semu bertujuan untuk memperoleh informasi yang merupakan perkiraan bagi informasi yang dapat diperoleh dengan eksperimen yang sebenarnya dalam keadaan yang tidak memungkinkan untuk mengontrol semua variabel yang relevan. Rancangan penelitian yang digunakan dalam penelitian ini adalah rancangan faktorial 2 x 2 yang desainnya ditentukan berdasarkan pendapat Ary, Jacobs \& Razavieh (2005:391). Adapun pola rancangan penelitian tersebut terlihat pada gambar berikut.Teknik sampling yang digunakan adalah multy-stage purposive random sampling, Teknik analisis data yang digunakan dalam penelitian ini adalah analisis data secara inferensial. Analisis inferensial ini dilakukan untuk kepentingan pengujian hipotesis penelitian digunakan untuk menarik kesimpulan. Untuk kepentingan ini, data penelitian dianalisis dengan menggunakan teknik analisis of variance (ANAVA) dengan menggunakan program software SPSS versi 13 . Teknik analisis data yang diggunakan ada dua macam analisis, yaitu: Analisis Data Secara Deskriptif dan Analisis Data Secara Inferensial

\section{Hasil dan Pembahasan}

Hasil penelitian akan dilaporkan melalui dua tahap, yaitu (1) secara deskriptif dan (2) secara inferensial. Laporan secara deskriptif dilengkapi dengan tabel frekuensi, histogram.Sedangkan laporan secara inferensial menyajikan hasil uji asumsi yang berupa uji normalitas dan homogenitas populasi serta hasil analisisi statistik dengan Anava dua jalan.Berdasarkan variabel-variabelnya, maka hasil penelitian ini dilaporkan sebagai berikut.

\section{Kualitas Pelaksanaan Gerakan Literasi Sekolah Yang Tinggi}

Setelah dilakukan analisis deskriptif, nilai-nilai yang didapatkan yaitu: $\mathrm{n}$ sebanyak 68; nilai minimal ( $\min )$ sebesar 69; nilai maksimal ( $\max$ ) sebesar 100; rata-rata $(\mathrm{Mn})$ 84.85; standar deviasi (SD) sebesar 8.89; nilai pertengahan (Me) sebesar 86.00; nilai modus (Mo) sebesar 86.00. Dari data yang telah dianalisis tersebut, disusun daftar distribusi frekuensi berdasarkan Sturges. Dengan panjang rentangan selisih data terbesar dikurangi data terkecil $(r): 34$, banyak kelas interval $(k): 7$ dan panjang interval (c) : 5 , diperoleh distribusi frekuensi sebagai berikut, 
Tabel 1. Distribusi Frekuensi Data Gerakan Literasi Sekolah yang Tinggi

\begin{tabular}{ccc}
\hline Kelas Interval & Frekuensi & Persentase \\
\hline $69-73$ & 9 & $13,24 \%$ \\
\hline $74-78$ & 12 & $17,65 \%$ \\
\hline $79-83$ & 8 & $11,76 \%$ \\
\hline $84-88$ & 12 & $17,65 \%$ \\
\hline $89-93$ & 14 & $20,59 \%$ \\
\hline $94-98$ & 10 & $14,71 \%$ \\
\hline $99-103$ & 3 & $4,41 \%$ \\
\hline & 68 & $100 \%$ \\
\hline
\end{tabular}

Kualitas Pelaksanaan Gerakan Literasi Sekolah Rendah

Setelah dilakukan analisis deskriptif, nilai-nilai yang didapatkan yaitu: $\mathrm{n}$ sebanyak 52; nilai minimal ( $\mathrm{min}$ ) sebesar 66; nilai maksimal (max) sebesar 95; rata-rata $(\mathrm{Mn})$ 80.00; standart deviasi (SD) sebesar 8.22; nilai pertengahan (Me) sebesar 80.92; nilai modus (Mo) sebesar 80.92. Dari data yang telah dianalisis tersebut, disusun daftar distribusi frekuensi berdasarkan Sturges. Dengan panjang rentangan $(r): 29$, banyak kelas interval (k) : 7 dan panjang interval (c) : 5, diperoleh distribusi frekuensi sebagai berikut:

Tabel 2: Distribusi Data Kualitas Pelaksanaan Gerakan Literasi Rendah

\begin{tabular}{ccc}
\hline Kelas Interval & Frekuensi & Persentase \\
\hline $66-70$ & 5 & $9,62 \%$ \\
\hline $71-75$ & 8 & $15,38 \%$ \\
\hline $76-80$ & 15 & $28,85 \%$ \\
\hline $81-85$ & 6 & $11,54 \%$ \\
\hline $86-90$ & 9 & $17,31 \%$ \\
\hline $91-95$ & 9 & $17,31 \%$ \\
\hline & 52 & $100 \%$ \\
\hline
\end{tabular}

\section{Minat Baca Tinggi}

Setelah dilakukan analisis deskriptif, nilai-nilai yang didapatkan yaitu: $\mathrm{n}$ sebanyak 65; nilai minimal ( $\min )$ sebesar 75; nilai maksimal (max) sebesar 100; rata-rata $(\mathrm{Mn})$ 89.57; standart deviasi (SD) sebesar 5.75; nilai pertengahan (Me) sebesar 90.00; nilai modus (Mo) sebesar 90.00. Dari data yang telah dianalisis tersebut, disusun daftar distribusi frekuensi berdasarkan Sturges. Dengan panjang rentangan $(r): 28$, banyak kelas interval $(k): 7$ dan panjang interval (c ) : 5, diperoleh distribusi frekuensi seperti pada tabel 3. 
Tabel 3: Distribusi Frekuensi Minat Baca Tinggi

\section{Minat Baca Rendah}

\begin{tabular}{|c|c|c|}
\hline Kelas Interval & Frekuensi & Persentase \\
\hline $75-79$ & 5 & $7,69 \%$ \\
$80-83$ & 2 & $3,08 \%$ \\
$84-87$ & 13 & $20,00 \%$ \\
$88-91$ & 20 & $30,77 \%$ \\
$92-95$ & 16 & $24,62 \%$ \\
$96-99$ & 7 & $10,77 \%$ \\
$100-103$ & 2 & $3,08 \%$ \\
& 65 & $100 \%$ \\
\hline
\end{tabular}

Setelah dilakukan analisis deskriptif, nilai-nilai yang didapatkan yaitu: $\mathrm{n}$ sebanyak 65; nilai minimal ( $\min$ ) sebesar 66; nilai maksimal ( $\max$ ) sebesar 83; rata-rata $(\mathrm{Mn})$ 75.56; standart deviasi (SD) sebesar 4.70; nilai pertengahan (Me) sebesar 76.00; nilai modus (Mo) sebesar 76.00.. Dari data yang telah dianalisis tersebut, disusun daftar distribusi frekuensi berdasarkan Sturges. Dengan panjang rentangan $(r): 17$, banyak kelas interval (k) : 7 dan panjang interval (c) : 3, diperoleh distribusi frekuensi sebagai berikut: Tabel 4. Distribusi Frekuensi Minat Baca Rendah

\begin{tabular}{|c|c|c|}
\hline Kelas Interval & Frekuensi & Persentase \\
\hline $66-68$ & 5 & $9,09 \%$ \\
$69-71$ & 7 & $12,73 \%$ \\
$72-74$ & 11 & $20,00 \%$ \\
$75-77$ & 10 & $18,18 \%$ \\
$78-80$ & 12 & $21,82 \%$ \\
$81-83$ & 10 & $18,18 \%$ \\
& 55 & $100 \%$ \\
\hline
\end{tabular}

Hasil Belajar Berbicara Siswa dengan Kualitas Pelaksanaan Gerakan Literasi Tinggi dan Minat Baca Tinggi

Setelah dilakukan analisis deskriptif, nilai-nilai yang didapatkan yaitu: $n$ sebanyak 39; nilai minimal ( $\min$ ) sebesar 84.00; nilai maksimal ( $\max$ ) sebesar 100; rata-rata $(\mathrm{Mn})$ 91.46; standart deviasi (SD) sebesar 4.62. Dari data yang telah dianalisis tersebut, disusun daftar distribusi frekuensi berdasarkan Sturges. Dengan banyak kelas interval (k): 6 dan panjang interval (c ): 3, diperoleh distribusi frekuensi sebagai berikut

Tabel 5. Hasil Belajar Berbicara Siswa dengan Kualitas Pelaksanaan Gerakan Literasi Tinggi dan Minat Baca Tinggi

\begin{tabular}{ccc}
\hline Kelas Interval & Frekuensi & Persentase \\
\hline $84-86$ & 6 & $15,38 \%$ \\
\hline $87-89$ & 9 & $23,08 \%$ \\
\hline $90-92$ & 8 & $20,51 \%$ \\
\hline $93-95$ & 7 & $17,95 \%$ \\
\hline $96-98$ & 6 & $15,38 \%$ \\
\hline $99-101$ & 3 & $7,69 \%$ \\
\hline & 39 & $100 \%$ \\
\hline
\end{tabular}




\section{Hasil Belajar Berbicara Siswa dengan Kualitas Pelaksanaan Gerakan Literasi Tinggi dan Minat Baca Rendah}

Setelah dilakukan analisis deskriptif, nilai-nilai yang didapatkan yaitu: $n$ sebanyak 29; nilai minimal ( $\min$ ) sebesar 69.00; nilai maksimal ( $\max$ ) sebesar 83; rata-rata $(\mathrm{Mn})$ 75.97; standart deviasi (SD) sebesar 4.013. Dari data yang telah dianalisis tersebut, disusun daftar distribusi frekuensi berdasarkan Sturges. Dengan banyak kelas interval (k) : 5 dan panjang interval (c ) : 3, diperoleh distribusi frekuensi sebagai berikut:

Tabel 6: Distribusi Frekuensi Gerakan Literasi Tinggi dan Minat Baca Rendah

\begin{tabular}{|c|c|c|}
\hline Kelas Interval & Frekuensi & Persentase \\
\hline $69-71$ & 5 & $17,24 \%$ \\
$72-74$ & 6 & $20,69 \%$ \\
$75-77$ & 7 & $24,14 \%$ \\
$78-80$ & 6 & $20,69 \%$ \\
$81-83$ & 5 & $17,24 \%$ \\
& 29 & $100 \%$ \\
\hline
\end{tabular}

Hasil Belajar Berbicara Siswa dengan Kualitas Pelaksanaan Gerakan Literasi Rendah dan Minat Baca Tinggi

Setelah dilakukan analisis deskriptif, nilai-nilai yang didapatkan yaitu: $\mathrm{n}$ sebanyak 26; nilai minimal ( $\mathrm{min}$ ) sebesar 75.56; nilai maksimal (max) sebesar 95; rata-rata $(\mathrm{Mn})$ 86.73; standart deviasi (SD) sebesar 6.19. Dari data yang telah dianalisis tersebut, disusun daftar distribusi frekuensi berdasarkan Sturges. Dengan banyak kelas interval (k) : 6 dan panjang interval (c) : 4, diperoleh distribusi frekuensi sebagai berikut:

Tabel 7. Distribusi Hasil Berbicara Siswa dengan Kualitas Gerakan Literasi Rendah dan Minat Baca Tinggi

\begin{tabular}{ccc}
\hline Kelas Interval & Frekuensi & Persentase \\
\hline $75-78$ & 5 & $19,23 \%$ \\
\hline $79-82$ & 2 & $7,69 \%$ \\
\hline $83-86$ & 3 & $11,54 \%$ \\
\hline $87-90$ & 7 & $26,92 \%$ \\
\hline $91-94$ & 8 & $30,77 \%$ \\
\hline $95-98$ & 1 & $3,85 \%$ \\
\hline & 26 & $100 \%$
\end{tabular}

Hasil Belajar Berbicara Siswa dengan Kualitas Pelaksanaan Gerakan Literasi Rendah dan Minat Baca Rendah

Setelah dilakukan analisis deskriptif, nilai-nilai yang didapatkan yaitu: $\mathrm{n}$ sebanyak 26; nilai minimal ( $\min )$ sebesar 66.00; nilai maksimal ( $\max$ ) sebesar 83; rata-rata $(\mathrm{Mn})$ 75.12; standart deviasi (SD) sebesar 5.41. Dari data yang telah dianalisis tersebut, disusun daftar distribusi frekuensi berdasarkan Sturges. Dengan banyak kelas interval (k) : 6 dan panjang interval (c) : 3, diperoleh distribusi frekuensi sebagai berikut: 
Tabel 8. Distribusi Frekuensi Prestasi Berbicara Siswa dengan Kualitas Pelaksanaan Gerakan Literasi Rendah dan Minat baca Rendah

\begin{tabular}{|c|c|c|}
\hline Kelas Interval & Frekuensi & Persentase \\
\hline $66-68$ & 5 & $19,23 \%$ \\
$69-71$ & 2 & $7,69 \%$ \\
$72-74$ & 5 & $19,23 \%$ \\
$75-77$ & 3 & $11,54 \%$ \\
$78-80$ & 6 & $23,08 \%$ \\
$81-83$ & 5 & $19,23 \%$ \\
& 26 & $100 \%$ \\
\hline
\end{tabular}

\section{Pembahasan}

Perbedaan Hasil Belajar Berbicara antara Siswa pada Kualitas Pelaksanaan Gerakan Tinggi dengan Siswa pada Kualitas Pelaksanaan Gerakan Rendah

Setelah dilakukan analisis statistik Anava dua jalan, nilai rata-rata hasil belajar kelompok kualitas pelaksanaan gerakan literasi sekolah tinggi sebesar 84,85, lebih tinggi dibanding dengan kualitas pelaksanaan gerakan literasi sekolah rendah sebesar 80,92. Dari data tersebut dapat disimpulkan bahwa ada perbedaan hasil belajar berbicara siswa terhadap pelaksanaan gerakan literasi sekolah. Hal tersebut sejalan dengan pendapat Djamarah (2011:13) bahwa belajar adalah serangkaian kegiatan jiwa raga untuk memperoleh suatu perubahan tingkah laku sebagai hasil dari pengalaman individu dalam interaksi dengan lingkungannya yang menyangkut kognitif, afektif, dan psikomotor. Begitu juga dengan Suyono ( 2011:44) menyatakan bahwa literasi sebagai basis pengembangan pembelajaran efektif dan produktif memungkinkan siswa terampil mencari dan mengolah informasi yang sangat dibutuhkan dalam kehidupan berbasis ilmu pengetahuan abad 21. Salah satu program yang dicanangkan pemerintah untuk memaksimalkan penerapan GLS dan memaksimalkan dalam mengintergrasikan literasi dengan kurikulum pembelajaran.

Beberapa penelitian menunjukkan kualitas pendidikan menjadi kebutuhan.Dalam penelitiannya Surangangga (2017) menyatakan bahwa Pendidikan yang berkualitas menjadi kebutuhan penting di era persaingan global yang kian kompetitif. Para pengambil kebijakan di tingkat pusat pastinya sudah menyadari akan hal tersebut. Untuk menjadikan dunia pendidikan berkualitas, tentu sangat banyak faktor yang berkaitan dan saling memengaruhi.Salah satu upaya pemerintah menjadikan pendidikan berkualitas adalah melalui meningkatkan budaya literasi (membaca dan menulis). Pemerintah melalui Permendikbud Nomor 23 Tahun 2015 telah menyadari pentingnya penumbuhan karakter peserta didik melalui kebijakan membaca selama 15 menit sebelum pelajaran dimulai. Namun untuk menyukseskan rencana besar ini, tidak bisa instant dan bersifat temporary. Yang akan dibangun itu adalah kebiasaan, maka dibutuhkan suatu pembiasaan yang harus terus menerus dilakukan sejak usia dini dan untuk itu konsistensi sangat diperlukan. Tentu tugas ini terasa berat untuk diterapkan kepada siswayang akan dibangun itu adalah kebiasaan, maka dibutuhkan suatu pembiasaan yang harus terus menerus dilakukan sejak usia dini dan untuk itu konsistensi sangat diperlukan. Tentu tugas ini terasa berat untuk diterapkan kepada siswa manakala 
gurunya tidak ikut terbiasa membaca buku. Ada banyak kegiatan pembiasaan untuk memulai gerakan literasi sekolah, yang terpenting adalah kemauan dari seluruh warga sekolah untuk mensukseskan program tersebut, diantaranya mendekatkan buku sedekat mungkin dengan anak-anak, kemudahan dalam mengakses buku seperti adanya gerobak baca, tersedianya sudut baca maupun lainnya dan tentu saja adanya suplai buku seperti hibah buku dari wali murid maupun masyarakat lainnya. Dalam mensukseskan program literasi sekolah, tentu harus adanya keteladanan dari semua pihak, bukan hanya guru, tetapi juga kepala sekolah, sampai penjaga sekolah.

\section{Perbedaan Hasil Belajar Berbicara antara Siswa dengan Minat Baca Tinggi dan Minat Baca Rendah.}

Sesuai dengan kenyataan yang diperoleh dari simpulan penelitian bahwa nilai rata-rata hasil belajar siswa pada kelompok siswa dengan minat baca tinggi sebesar 89,57, lebih tinggi dibandingkan dengan kelompok siswa dengan minat baca rendah sebesar 75,56. Hal ini membuktikan bahwa minat baca menjadi kunci keberhasilan proses belajar. Sejalan dengan pendapat Rahim (2008:28) yang mengemukaan bahwa, "minat baca adalah keinginan yang kuat disertai usaha usaha seseorang untuk membaca .sesorang yang mempunyai minat baca yang kuat akan diwujudkan dalam kesediaannya untuk mendapatkan bahan bacaan dan kkemudian membacaanya atas kesadaran sendiri". Dari beberapa penelitian menunjukkan bahwa minat baca berperan dalam hasil belajar siswa. Dalam penelitian Adam (2018) tentang minat baca sangat berperan terhadap hasil belajar siswa. Dengan minat baca tinggi akan membuat siswa rajin membaca. Minat yang baik akan memungkinkan untuk memperoleh serta mendapat prestasi dari setiap individu yang beraktifitas, lebuh lebih dalam korelasinya dengan hasil belajar.

Interaksi antara Kualitas Pelaksanaan Gerakan Literasi dan Minat Baca Terhadap Prestasi Berbicara Siswa.

Hasil analisis penelitian ini menunjukkan bahwa nilai rata-rata pemahaman kelompok gerakan literasi sekolah tinggi dan minat baca tinggi sebesar 83,714 , sedikit lebih tinggi dibandingkan dengan gerakan literasi rendah dengan minat baca rendah sebesar 80,923 . Meskipun sedikit lebih tinggi namun peran minat baca adalah penting. Banyak faktor yang mempengaruhi hasil belajar siswa, diantaranya adalah kualitas penerapan gerakan literasi sekolah dan minat baca siswa. Hasil analisis penelitian ini relevan dengan hasil penelitian Faradina (2017) yaitu ada pengaruh program gerakan literasi sekolah terhadap minat baca atau dengan kata lain bukti menunjukkan bahwa terdapat pengaruh program gerakan literasi sekolah terhadap minat baca siswa signifikan. Dengan demikian ada interaksi antara program sekolah dan minat baca dalam meningkatkan hasil belajar berbicara siswa. Minat sangat berpengaruh pada kegiatan belajar siswa. Ada tidaknya minat seseorang individu untuk belajar sangat berpengaruh dalam proses aktivitas belajar itu sendiri. Hasil pada penelitian ini menunjukkan bahwa nilai rata-rata hasil belajar siswa pada kualitas pelaksanaan gerakan literasi tinggi dan minat baca tinggi sebesar 89,096, lebih tinggi dibandingkan dengan hasil belajar siswa pada kualitas pelaksanaan gerakan literasi rendah sebesar 75,540. Hal tersebut menunjukkan peran minat baca berpengaruh pada hasil belajar berbicara siswa. 


\section{Kesimpulan}

Ada pengaruh kualitas pelaksanaan gerakan literasi sekolah terhadap hasil belajar berbicara siswa SD Negeri segugus Taman. Nilai F hitung uji beda pemahaman antara kelompok kualitas pelaksanaan gerakan literasi tinggi dengan kualitas pelaksanaan gerakan literasi rendah sebesar 8,929 dengan signifikansi sebesar 0,003 $<0,05$, maka disimpulkan bahwa ada perbedaan yang signifikan hasil belajar siswa antara kelompok kualitas pelaksanaan gerakan literasi tinggi dengan kualitas pelaksanaan gerakan literasi rendah. Ada pengaruh minat baca terhadap prestasi berbicara siswa SD Negeri segugus Taman. Siswa dengan minat baca tinggi mempunyai rerata nilai yang lebih tinggi daripada siswa dengan minat baca rendah. Nilai $F$ hitung uji beda pemahaman antara kelompok minat baca tinggi dengan minat baca rendah sebesar 210,724 dengan signifikansi sebesar 0,000. Karena nilai signifikansi $0,000<0,05$, maka dapat disimpulkan bahwa ada perbedaan yang signifikan hasil belajar siswa antara kelompok minat baca tinggi dengan minat baca rendah. Ada interaksi antara kualitas pelaksanaan literasi dan minat baca terhadap prestasi belajar berbicara siswa SD Negeri segugus Taman . Nilai F hitung uji sebesar 4,317 dengan dengan signifikansi sebesar 0,040. Karena nilai signifikansi 0,040 $<0,05$, maka dapat disimpulkan bahwa ada perbedaan yang signifikan hasil belajar siswa ditinjau dari antara pelaksanaan gerakan literasi dengan minat baca.

\section{Daftar Pustaka}

Adelina, N. dkk. (2016). Tema 2 Macam-macam Peristiwa dalam Kehidupan Buku Tematik Terpadu kurikulum 2013:Buku Siswa SD Kelas V. Pusat Kurikulum dan Perbukuan, Kemdikbud.

Adelina, N. (2016). Tema 2 Macam-macam Peristiwa dalam Kehidupan Buku Tematik Terpadu kurikulum 2013:Buku Guru SD Kelas V. Pusat Kurikulum dan Perbukuan, Kemdikbud.

Anita W, Sri dkk, (2008). Strategi Pembelajaran di SD, Jakarta: Universitas Terbuka

Arikunto, S. (1989). Dasar- dasar Evaluasi Pendidikan. Jakarta: Bina Aksara

Beers, C. S., Beers, J. W., \& Smith, J. O. (2009). A Principal's Guide toLiteracy Instruction. New York: Guilford Press.

Borg,Walter R \& Gall, Meredith Damien.(1979). Education Research; An Introcduction Third Editions. London: Longman.

Crow and Crow.( 1973). An Outline of Psicology .Terjemahan oleh Shaleh dan Wahab, Jakarta: Kencana

Darmono, (2001). Manajemen Perpustakaan Sekolah. Jakarta: Grasindo

Faradina, N. (2017). Pengaruh Program Gerakan Literasi Sekolah terhadap Minat Baca Siswa di SD Islam Terpadu Muhammadiyah An-Najah Jatinom Klaten. Hanata Widya, 6(8), 60-69.

Fauzah, D. U., dkk. (2016). Panduan Gerakan Literasi sekolah di Sekolah Dasar. Jakarta: Direktorat Jenderal Pendidikan Dasar dan MenengahKementerian Pendidikan dan Kebudayaan

Gagne, E.D. (1985). The Cognitive Psychology of School Learning. Boston- Toronto: Litle, Brown and Company. 
Gail, E., Brewster, J., \& Mohammed, S. (1991). Storytelling Handbookfor Primary Teachers. England: Penguin.

Hamilton, E. W. (2009). Raising Bookworms: Getting Kids Reading for Pleasure and Empowerment. Sag Harbour, NY: Beech Tree Books.

Hartono, R. (2013). Ragam Model mengajar yang mudah diterima murid. Jogyakarta: Diva Press

Hamalik, O. (2007). Proses Belajar Mengajar. Jakarta : Bumi Aksara

Hemati, H dan Moradi, M. (2013). Manajemen Pembelajaran. Surabaya: PT STAIN Salatiga Press

Hermanto, B. (2012). Pengaruh Prestasi Trainin, Motivasi Dan Masa Kerja Teknisi Terhadap Produktivitas Teknisi Di Bengkel Nissan Yogyakarta, Solo, dan Semarang. Skripsi. Universitas Negeri Yogyakarta.

Joyce, B and Weil, M.(1996). Models of Teaching. Boston: Allyn and Bacon.

Kasihani. (2009). Model-model Pembelajaran. Malang: Universitas Negeri Malang.

Iskandarwassid dan Suhendar. (2015). Strategi Pembelajaran Bahasa. Bandung: PT.Remaja Rosdakarya

Ismawati, E. dan Umaya, F. (2012). Belajar Bahasa Di kelas Awal. Yogyakarta: PT. Ombak

Al-Tabany, T. I. B. (2014). Mendesain model pembelajaran inovatif, progresif, dan kontekstual. Jakarta: Prenadamedia Group.

Kundharu dan St. Y. Slamet. (2005). Pembelajaran Keterampilan Berbahasa Indonesia.Yogyakarta: Graha IImu

Mullis, I. V.S, et al. (2012). PIRLS, 2011 International Results in Reading. TIMS \& PIRLS Study Center, Boston: Lynch School of Education.

Musbikin, I. (2004). Mendidik Anak Kreatif Ala Eistein. Yogyakarta: Mitra Pustaka.

Nurgiantoro, B. (2009). Penilaian dalam Pengajaran Bahasa dan Sastra edisi 3. Yogyakarta: Penerbit BPFE Yogyakarta.

Nurgiantoro, B. (2011). Penilaian Otentik dalam Pembelajaran Bahasa. Yogyakarta: Gajahmada University Press.

OECD. (2014). PISA 2012 Results in Focus: What 15-year-olds Know andWhat They Can Do with What They Know. New YORK: Colombia University

Peraturan Menteri Pendidikan dan Kebudayaan RI Nomor 23 Tahun 2013 tentang Standar Pelayanan Minimal Pendidikan Dasar di Kabupaten/ Kota.

Peraturan Menteri Pendidikan dan Kebudayaan RI Nomor 23 Tahun 2015 tentang Penumbuhan Budi Pekerti.

Prasetyono, D. (2008). Rahasia Mengajarkan Gemar Membaca Pada Anak Sejak Dini. Jogyakarta: Think

Purwanto, A. E. \& Sulistyastuti, D.R. (2011). Metode Penelitian Kuantitatif untuk administrasi public dan masalah-masalah sosial. Yogyakarta; Penerbit Gava Media

Rahim, F. (2008). Pengajaran Membaca di Sekolah Dasar. Jakarta: Bumi Aksara 
Ricard, K. (2000). Literacy \& Language Teaching, oxford. New York: Oxford University Press.

Sanjaya, W. (2015). Strategi pembelajaran berorentasi Standar Proses. Jakarta: Kencana

Slameto, S.( 2013). Belajar dan faktor-faktor yang mempengaruhi. Jakarta: PT Reika Cipta

Sudijono, A. (2012). Pengantar Evaluasi Pendidikan. Jakarta: Grasindo

Sugiyono. (2013). Metode Penelitian Pendidikan Pendekatan Kuantitatif, kualitatif, dan $R \& D$. Bandung: Alfabeta

Suhartono, S. (2005). Pengembangan Keterampilan Berbicara Anak Usia Dini. Jakarta: Departemen Pendidikan Nasional

Suragangga, I. M. N. (2017). Mendidik lewat literasi untuk pendidikan berkualitas. Jurnal Penjaminan Mutu, 3(2), 154-163.

Suyono. (2011). Pembelajaran Efektif dan Produktif Berbasis Literasi; Analisis konteks, prinsip, dan wujud alternative Strategi Implementasinya di Sekolah. Malang: Penerbit Cakrawala Indonesia

Syaiful.(2011). Psikologi Belajar. Jakarta: Rineka Cipta

T.W.Solchan. (2013).Pendidikan Bahasa Indonesia di SD.Jakarta.Universitas Terbuka

Tarigan,H.G. (2008). Berbicara sebagai Suatu Keterampilan Berbahasa. Bandung: Angkasa

UNESCO. (2005). Development of Information Literacy: Through SchoolLibraries in Southeast Asia Countries. Bangkok. UNESCO

UNESCO. (2003). The Prague Declaration. "Towards an Information Literate Society". Bangkok.UNESCO

Uzer Usman, M. dan Setyowati, L. (2006). Upaya Optimalisasi Kegiatan Belajar. Bandung: Remaja Rosdakarya 